\title{
Economic rationale for typical energy-saving solutions for individual residential construction
}

\author{
Anna Minnullina ${ }^{1, *}$, and Natalya Solopova $^{2}$ \\ ${ }^{1}$ Industrial University of Tyumen, Volodarskogo St., 38, Tyumen, 625000, Russia \\ ${ }^{2}$ Moscow State University of Civil Engineering (National Research University), Yaroslavskoye \\ Shosse, 26, Moscow, Russia
}

\begin{abstract}
The article reflects energy-saving measures in individual residential construction in relation to the Tyumen region of Russian Federation, which can be used for other regions of similar climatic conditions. Implementation of energy-saving measures entails costs; accordingly, methodology for calculating the payback periods of these recommendations was considered. The authors evaluated the heat loss of a typical residential building without taking into account application of measures after implementation in order to confirm the effectiveness of the application of proposed recommendations.
\end{abstract}

\section{Introduction}

Energy saving is one of the important tasks of the 21 st century, since the consumption of thermal and electric energy is a necessary condition for human life and creation of favorable living conditions [1]. Improving competitiveness, financial stability, economic and environmental security, as well as increasing the level and quality of life of the population is impossible without energy potential and energy efficiency through the modernization of technological development and transition to rational and environmentally responsible use of energy resources [2].

The entry of society into the circle of economically developed countries also depends on the results of solving this problem.

The task of energy saving is posed by the leadership of the Russian state in Federal Law of November 23, 2009 No. 261 "On Energy Saving and on Improving Energy Efficiency, and on Amending Certain Legislative Acts of the Russian Federation". It involves implementation of legal, industrial, organizational, scientific, technical and economic measures aimed at the efficient use of energy resources and involvement of renewable energy sources in the economy [3]. It is the main, but not the only regulatory document. So, to support energy saving measures, several dozens of normative acts, methodological and program documents have been adopted.

\footnotetext{
* Corresponding author: minnullinaay@yandex.ru
} 
At present, one of the most pressing problems is the search for energy-saving measures and engineering solutions for creating building envelopes of individual residential buildings with minimal heat loss [4]. A major role is played here by the creation of new building heat-insulating facing materials and products, as well as the development of new methods for determining the thermophysical properties of materials. New methods for calculating the thermophysical properties of materials and products make it possible to efficiently and adequately evaluate the thermal and air conditions of buildings. The problems of energy saving and reduction of heat loss in the environment significantly affect the environmental situation and capital costs of construction projects [5]. During construction at the facility, it is necessary to be able to determine the thermophysical properties of the materials used, since the actual characteristics of products may not correspond to the certificate or passport.

Key principles of the concept of an energy-efficient building are presented in Figure 1.

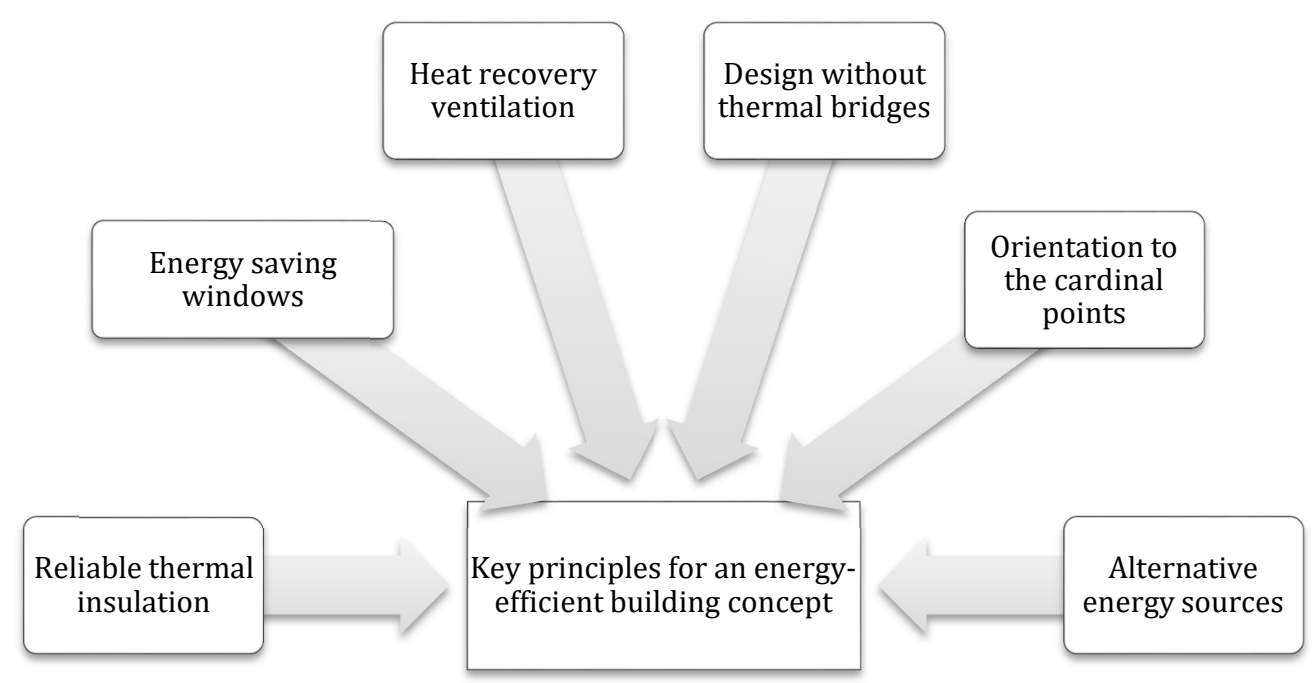

Fig. 1. Key principles of an energy-efficient building concept

Creating an energy-efficient home in Russia is extremely difficult for various reasons, including financial ones. Solution to the problem of energy saving and energy efficiency is long-term, due to the need to both change the system of relations in energy markets, and replace and modernize a large part of the engineering and social infrastructure and its development on a new technological base [6]. One of the most important conditions is the creation of energy saving as a profitable business for a company engaged in energy saving at a professional level. At the same time, energy saving should be transformed for energy consumers into a reasonable method of reducing costs [7]. In a market economy, consumers are willing to pay money, therefore it is extremely important to organize an energy- 
saving market by organizing needs for energy-saving goods and services that will not take long [8]. It is important to provide energy saving services in a timely manner, to establish contacts between organizations dealing with these problems.

\section{Methods}

In Russia, there are Territorial building codes, which normalize the average level of heat loss of a building. These values depend on the area of the building, as well as its geographical location. Energy efficiency is divided into classes. The class " $D$ " (normative) is taken as the reference point, and the rest are determined by the deviation (in \%) of the heat loss of the building from the standard. Table 1 shows the energy efficiency classes of houses.

Table 1. Classification of buildings in the Tyumen region

\begin{tabular}{|l|c|c|}
\hline $\begin{array}{c}\text { Classification of } \\
\text { buildings }\end{array}$ & $\begin{array}{c}\text { The value of deviations from the } \\
\text { normalized value, } \%\end{array}$ & $\begin{array}{c}\text { Energy costs } \\
\text { for heating } \\
\mathrm{kW} / \mathrm{m} 2 * \\
\text { year, Tyumen }\end{array}$ \\
\hline "A", very high & -40 and less & 124 \\
\hline "B", high & -30 to -40 & $145-124$ \\
\hline "C", hightened & -15 to -30 & $176-145$ \\
\hline "D", normal & 0 to -15 & $207-176$ \\
\hline "E", lowered & +35 to 0 & $279-207$ \\
\hline "F", low & +70 to +35 & $352-279$ \\
\hline "G", very low & more than $70 \%$ & 400 \\
\hline
\end{tabular}

The norms in Tyumen are significantly milder. Class "A" allows 8 times more losses than in a passive building. But it should also be noted that the "passive building" built in Europe will not be effective in Tyumen due to the temperate continental climate.

If for an energy-passive building in Europe, $300 \mathrm{~mm}$ of insulation on the walls is enough, in the climate of Tyumen $600-700 \mathrm{~mm}$ are required. This is a completely different level of initial investment.

Alternative sources of energy are also used in Europe, such as: heat of the earth, wind energy, solar energy [9].

During the construction of energy-efficient buildings, all proportions will immediately change, if, for example, the walls are substantially insulated. In this case, the proportion of losses through the walls will decrease, and the weight of other factors will increase.

Energy-efficient building projects have an increased thickness of thermal insulation to reduce losses through building envelopes. For example, in Europe, the thickness of the insulation of the walls of a private house starts from $300 \mathrm{~mm}$, and in our country from $50 \mathrm{~mm}$. Rational values for our country lie in the range of 150$200 \mathrm{~mm}$, since the payback period of investments in energy efficiency is up to 10 years. Longer investment horizons are not typical for our country. 
For the climate of the Tyumen region, the best solution would be the introduction of energy-saving measures, presented in Figure 2.

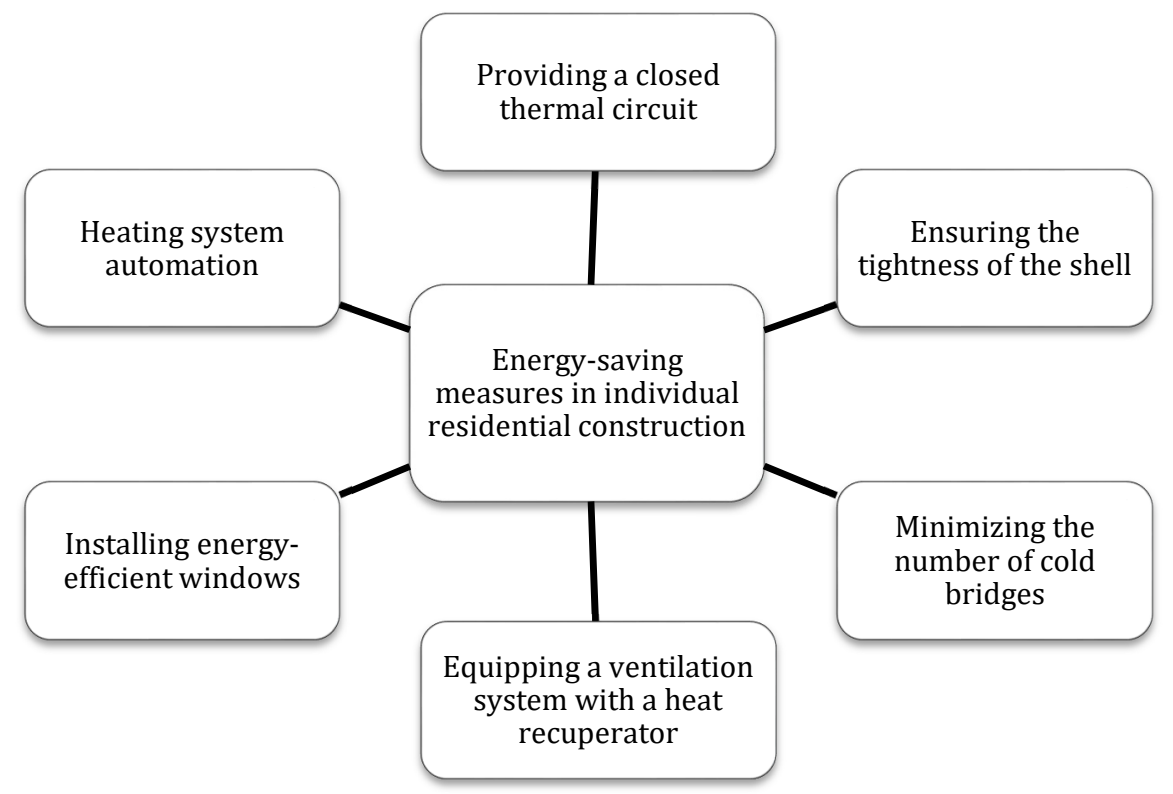

Fig. 2. Energy-saving measures in individual residential construction in the Tyumen region of Russia

Investing in energy-saving technologies, taking into account the payback period, is the right and effective solution based on the cost of energy resources.

However, before starting implementation of energy-saving measures, one should calculate the return on investment. For this, it is necessary to calculate the difference in operating costs for the introduction of a supply and exhaust unit with a rotary heat recuperator.

The cost of heat for heating the outdoor air in a system without a heat exchanger is calculated by the formula (1):

$$
Q_{p}^{i}=V p \frac{1}{3600} c_{p}\left(t_{s a}-t_{o}^{i}\right) \tau, \mathrm{kW} * \text { hour }
$$

$\mathrm{V}$ - outdoor air flow, $\mathrm{m}^{3} /$ hour; $\rho$ - outside air density, $\mathrm{kg} / \mathrm{m}^{3} ; \mathrm{c}_{\mathrm{p}}-$ specific heat at constant pressure, $\mathrm{kJ} /\left(\mathrm{kg}^{*}{ }^{\circ} \mathrm{C}\right) ; \mathrm{t}_{\mathrm{sa}}-$ supply air temperature, ${ }^{\circ} \mathrm{C} ; t_{o}^{i}-$ outdoor temperature, ${ }^{\circ} \mathrm{C} ; \tau$ - duration of constant outdoor air temperature, hours.

The air temperature at the outlet of the rotary regenerator is calculated by the formula (2):

$$
t_{o 1}^{i}=t_{o}^{i}+\varepsilon\left(t_{r 1}-t_{o}^{i}\right),{ }^{\circ} \mathrm{C}
$$

$t_{r 1}^{i}$ - temperature of air removed from the room, ${ }^{\circ} \mathrm{C} ; t_{o}^{i}$ - outdoor temperature, ${ }^{\circ} \mathrm{C} ; \varepsilon$ - rotor efficiency, $\%$.

The amount of heat required to heat the outside air from the temperature at the outlet of the regenerator to the parameters on the inflow is calculated by the formula (3):

$$
Q_{p, \mathrm{yT}}^{i}=V p \frac{1}{3600} c_{p}\left(t_{s a}-t_{o 1}^{i}\right) \tau, \mathrm{kW} * \text { hour }
$$


$\mathrm{V}$ - outdoor air flow, $\mathrm{m}^{3} /$ hour; $\rho$ - outside air density, $\mathrm{kg} / \mathrm{m}^{3} ; \mathrm{c}_{\mathrm{p}}-$ specific heat capacity at constant pressure, $\mathrm{kJ} /\left(\mathrm{kg}^{* \circ} \mathrm{C}\right) ; \mathrm{t}_{\mathrm{sa}}-$ supply air temperature, ${ }^{\circ} \mathrm{C} ; t_{o}^{i}-$ outside air temperature, ${ }^{\circ} \mathrm{C} ; \tau$ - duration of constant outdoor air temperature, hours.

The amount of energy saved is calculated by the formula (4):

$$
\Delta \mathrm{Q}=\mathrm{Q}_{\mathrm{p}}-\mathrm{Q}_{\mathrm{p}, \mathrm{ot}}, k W * \text { hour } / \text { ?ear }
$$

$\mathrm{Q}_{\mathrm{p}}$ - heat consumption for heating outdoor air in a system without a heat exchanger, $\mathrm{kW}^{*}$ hour/year; $\mathrm{Q}_{\mathrm{p}, \mathrm{ot}}$ - amount of heat required to heat the outdoor air from the temperature at the outlet of the regenerator to the parameters on the inflow, $\mathrm{kW}^{*}$ hour/year;

The cost of energy saved is calculated by the formula (5):

$$
\ni=\Delta Q * \Pi \text {, rubles/year }
$$

$\Delta \mathrm{Q}$ - количество energy saved, $\mathrm{kW} * \mathrm{~h} / \mathrm{year} ; \Pi$ - cost of electric energy, rub / (kW $*$ h).

Next, it is necessary to calculate the difference in operating costs through the external enclosing structures.

The average heating power over the heating period is determined by the formula (6):

$$
Q=\frac{t_{i}-t_{o}^{a v}}{R}, \mathrm{~W} / m^{2}
$$

$\mathrm{t}_{\mathrm{i}}$ - indoor air temperature in a residential building, ${ }^{\circ} \mathrm{C} ; t_{o}^{a v}$ - average outdoor temperature during the heating period, ${ }^{\circ} \mathrm{C} ; R$ - thermal resistance, $\mathrm{m}^{2 * \circ} \mathrm{C} / \mathrm{W}$.

After that, heat savings for the heating period are calculated by the formula (7):

$$
\Delta \mathrm{Q}=\left(\mathrm{Q}_{1}-\mathrm{Q}_{2}\right) * \mathrm{n} * \mathrm{~S}, \mathrm{~kW} * \mathrm{~h}
$$

$\mathrm{Q}_{1}$ - average heating capacity for the heating period before the introduction of an energy-saving measure, $\mathrm{kW} / \mathrm{m}^{2} ; \mathrm{Q}_{2}$ - average heating capacity for the heating period after the introduction of an energy-saving measure, $\mathrm{kW} / \mathrm{m}^{2} ; \mathrm{n}$ - duration of the heating period, $\mathrm{h} ; \mathrm{S}-$ enclosing area, $\mathrm{m}^{2}$.

The cost of energy saved is calculated by the formula (8):

$$
\ni=\Delta Q * \Pi \text {, rubles/year }
$$

where $\Delta \mathrm{Q}$ - amount of energy saved, $\mathrm{kW}^{*} \mathrm{~h} /$ year; $\Pi$ - cost of electric energy, rubles $/\left(\mathrm{kW}^{*} \mathrm{~h}\right)$.

Evaluation of the economic efficiency of energy saving measures and calculation of payback periods should be performed using the reduced cost method.

The payback period can be calculated using the formula (9):

$$
T=\frac{K}{E}, \text { years }
$$

$\mathrm{K}$ - difference in the estimated cost of work, rubles; $\mathrm{E}$ - cost of energy saved, rubles/year.

The payback period calculated by this formula does not take into account:

- increase in tariffs for thermal energy;

- discounting future cash receipts achieved as a result of implementation of considered energy-saving measures and reduction of heat energy losses for heating.

For this reason, the value of the projected payback period of investments can be considered only as an estimate.

It should be noted that tariffs for heat and electricity are increasing annually. This means that with each subsequent year, the annual cash savings will increase. 
However, when considering this model, it should be borne in mind that the money saved in subsequent years should be calculated on the basis of the actual value of the money after a number of years, i.e. future cash flows should be discounted.

Given the above additional factors, the projected payback period of investments is determined by the formula (10):

$$
T=\frac{\ln \left[1+\frac{\kappa}{E} * \frac{(r-i)}{(1+i)}\right]}{\ln \left[\frac{1+r}{1+i}\right]}, \text { years }
$$

$r$ - average annual increase in the cost of heat tariffs; $i$ - discount rate; $K$ - the difference in the estimated cost of work, rubles; E - cost of energy saved, rubles.

This formula allows calculating the payback period of the energy-saving measure in question, taking into account the total capital costs of its implementation, loan payments, growth in the cost of heat energy tariffs, discounting, future cash flows achieved by saving money from the implementation of this energy-saving measure.

\section{Results}

The results of the application of proposed recommendations and corresponding calculations were carried out on the basis of the project data for the construction of an individual residential building provided by Baucraft LLC.

The residential project is a two-story building of a rectangular shape, locked with a garage for two cars, without a basement.

Heat losses of residential buildings have a significant effect due to the insufficient heat-insulating quality of the exterior walls, ceilings, basements and translucent fencing.

Characteristic of the heating season, adopted in the calculations for the city of Tyumen:

1. Estimated outdoor temperature $-35^{\circ} \mathrm{C}$;

2. Air temperature in the room $+22^{\circ} \mathrm{C}$;

3. The number of days of the heating season is 223 days.

The results of the heat engineering calculation of building envelopes are summarized in table 2 .

Table 2. Thermal resistance of building envelopes

\begin{tabular}{|l|c|}
\hline \multicolumn{1}{|c|}{ The name of the building envelope } & $\begin{array}{c}\text { Thermal resistance } \\
\text { real }\left(\mathrm{m} 2{ }^{\circ}{ }^{\circ} \mathrm{C}\right) / \mathrm{W}\end{array}$ \\
\hline Roof & 5.71 \\
\hline Outside Wall & 4.3 \\
\hline Windows & 0.65 \\
\hline Ground floor & 5.48 \\
\hline
\end{tabular}

The results of the calculation of heat loss through the enclosing structures of the initial project of a residential building are given in summary table 3 . 
Table 3. Heat losses through the building envelope of the original residential project

\begin{tabular}{|c|c|c|c|c|c|c|c|}
\hline \multirow{2}{*}{ № } & \multirow{2}{*}{ Name of premises } & \multicolumn{5}{|c|}{ Heat loss, W } & \multirow[t]{2}{*}{ Total } \\
\hline & & Floor & Walls & Windows & Roof & Ventilation & \\
\hline 1 & Entrance Tambour & 64 & 213 & - & - & - & 277 \\
\hline 2 & Hallway & 106 & - & - & - & 203 & 309 \\
\hline 3 & Living room & 482 & 427 & 1295 & - & 922 & 3126 \\
\hline 4 & Corridor & 119 & 232 & 147 & - & 226 & 724 \\
\hline 5 & $\begin{array}{l}\text { Kitchen-dining } \\
\text { room }\end{array}$ & 249 & 318 & 1341 & - & 1135 & 3043 \\
\hline 6 & Bathroom & 36 & 57 & - & - & 199 & 292 \\
\hline 7 & Parlour & 126 & 153 & 260 & - & 240 & 779 \\
\hline 8 & Wardrobe & 46 & - & - & - & 83 & 129 \\
\hline 9 & Garage & 564 & 850 & 260 & 596 & 1079 & 3349 \\
\hline 10 & $\begin{array}{l}\text { Room for heat } \\
\text { generator }\end{array}$ & 77 & 149 & 113 & 81 & 420 & 840 \\
\hline 11 & Pantry & 49 & 177 & 130 & 52 & 267 & 675 \\
\hline 12 & Hall & - & 232 & 147 & 139 & 252 & 770 \\
\hline 13 & Bedroom & - & 433 & 260 & 198 & 568 & 1459 \\
\hline 14 & Bedroom & - & 382 & 772 & 351 & 1135 & 2640 \\
\hline 15 & Bedroom & - & 382 & 772 & 351 & 1135 & 2640 \\
\hline 16 & Wardrobe & - & 109 & - & 77 & 397 & 583 \\
\hline 17 & Bathroom & - & 288 & 260 & 149 & 769 & 1466 \\
\hline \multicolumn{2}{|c|}{ Total: } & 1918 & 4402 & 5757 & 1994 & 9030 & 23101 \\
\hline
\end{tabular}

Calculated heat loss of the house is $\mathrm{Q}=23101 \mathrm{~W} * \mathrm{~h}$.

Heating costs for the year are summarized in table 4 .

Table 4. Heating costs for the year

\begin{tabular}{|l|c|}
\hline \multicolumn{1}{|c|}{ Tariffs } & $\begin{array}{c}\text { Heating costs for the year, } \\
\text { rub. }\end{array}$ \\
\hline Single-rate electricity tariff & 244800 \\
\hline Tariff for electricity, differentiated by two zones of the day & 206498 \\
\hline Tariff for electricity, differentiated by three zones of the day & 205829 \\
\hline
\end{tabular}

From table 4 it is seen that the tariff for electricity, differentiated by three zones of the day, comes out cheaper and amounts to 205829 rubles.

Figure 3 shows a graph of heat loss.

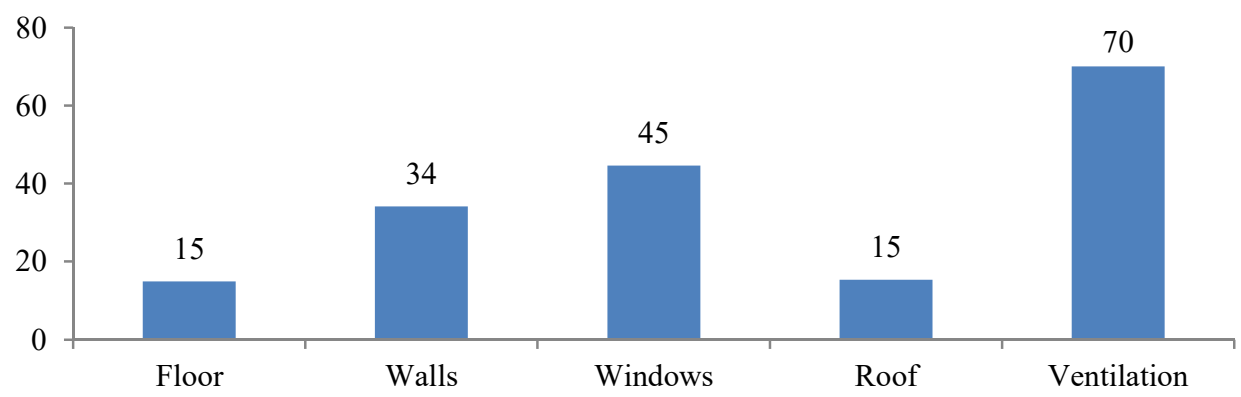

Fig. 3. Initial heat loss, $\mathrm{kW} / \mathrm{m} 2 *$ year 
Heat loss calculations count $179 \mathrm{~kW} / \mathrm{m} 2$ * year, which corresponds to the "D" energy efficiency class of buildings. The estimated costs of thermal energy for the heating season will amount to 205829 rubles.

An important element of the energy-saving concept of the heat supply system is the optimal solution for room ventilation. In this regard, in addition to the disconnected system of supply and exhaust ventilation, which was originally laid down in the project of a residential building, it is recommended to use mechanical recovery of the heat of the exhaust air, taking into account the payback. According to the data in table 3 , initial heat loss through ventilation is $9030 \mathrm{~W} * \mathrm{~h}$.

In accordance with the purpose and parameters of the ventilation-recuperative system, supply and exhaust ventilation with a rotary recuperator VU 500 is proposed; its payback is presented in table 5 .

Table 5. Calculation of the payback of the supply and exhaust unit with a rotary recuperator

\begin{tabular}{|l|c|c|}
\hline \multirow{2}{*}{ Indicators } & \multicolumn{2}{c|}{ Balanced ventilation unit (BVU) } \\
\cline { 2 - 3 } & without recovery & with recovery \\
\hline Cost of BVU, rub. & 89000 & 150000 \\
\hline \% of heat recovery & - & 80 \\
\hline Overpayment for installation, rub. & - & 61000 \\
\hline Expenses for heating the air per hour, kW & 4.91 & 0.98 \\
\hline Savings by the recuperator per year, rubles. & - & 31553.25 \\
\hline Cost of heating the air per year, rubles. & 39441.56 & 7888.31 \\
\hline $\begin{array}{l}\text { Payback period of BVU with recovery in } \\
\text { relation to BVU without recovery, years }\end{array}$ & - & 1.93 \\
\hline Costs of heating the air per 5 years, rubles. & 197207.82 & 39441.56 \\
\hline Costs of heating the air per 10 years, rubles. & 394415.64 & 78883.13 \\
\hline
\end{tabular}

The simple payback period of a balanced ventilation unit with recovery in relation to a balanced ventilation unit without recovery is 2 years. Estimated cash savings after 5 years can count 157766 rubles, after 10 years - 315523 rubles.

An important concept of an energy-efficient building is the thermal insulation of building envelopes. The considered project of a residential building fully complies with the standardized thermal performance, respectively, a further increase in the thermal insulation layer to reduce heat loss of the building should be calculated taking into account the payback.

The payback of an energy-saving measure to increase the heat-insulating layer of walls, roofs and foundations was calculated taking into account the cost of insulation and work per $1 \mathrm{~m} 2$ (table 6). So, the calculation of the payback of the thermal insulation of the walls was carried out with an increase in thickness of the insulation to $200 \mathrm{~mm}, 250 \mathrm{~mm}, 300$ $\mathrm{mm}$, thermal insulation of the foundation with an increase in the upper foundation plate of the insulation to $200 \mathrm{~mm}$, and thermal insulation of the roof with an increase in thickness of the insulation to $300 \mathrm{~mm}, 350 \mathrm{~mm}$. 
Table 6. The results of calculation of the payback of thermal insulation of walls, foundations and roofs

\begin{tabular}{|l|c|c|c|c|c|c|c|c|c|}
\hline \multirow{2}{*}{\multicolumn{1}{|c|}{ Indicators }} & \multicolumn{3}{|c|}{ Wall insulation thickness } & \multicolumn{2}{c|}{$\begin{array}{c}\text { Foundation } \\
\text { insulation } \\
\text { thickness }\end{array}$} & \multicolumn{3}{c|}{$\begin{array}{c}\text { Roof insulation } \\
\text { thickness }\end{array}$} \\
\cline { 2 - 11 } & $\begin{array}{c}150 \\
\mathrm{~mm}\end{array}$ & $\begin{array}{c}200 \\
\mathrm{~mm}\end{array}$ & $\begin{array}{c}250 \\
\mathrm{~mm}\end{array}$ & $\begin{array}{c}300 \\
\mathrm{~mm}\end{array}$ & $\begin{array}{c}150 \\
\mathrm{~mm}\end{array}$ & $\begin{array}{c}200 \\
\mathrm{~mm}\end{array}$ & $\begin{array}{c}250 \\
\mathrm{~mm}\end{array}$ & $\begin{array}{c}300 \\
\mathrm{~mm}\end{array}$ & $\begin{array}{c}350 \\
\mathrm{~mm}\end{array}$ \\
\hline $\begin{array}{l}\text { Cost of insulation } \\
\text { and work per 1 } \\
\text { m2, rubles. }\end{array}$ & $\begin{array}{c}2191.4 \\
3\end{array}$ & $\begin{array}{c}2921.9 \\
1\end{array}$ & 3652.48 & 4382.66 & 2721.43 & 3628.74 & 853.79 & 948.35 & 1042.91 \\
\hline $\begin{array}{l}\text { Overpayment for } \\
\text { installation, } \\
\text { rubles }\end{array}$ & 0 & 730.48 & 1461.05 & 2191.23 & 0 & 907.31 & 0 & 94.56 & 189.12 \\
\hline $\begin{array}{l}\text { Thermal } \\
\text { Resistance (m2 } \\
\text { K) / W }\end{array}$ & 4.3 & 5.32 & 6,34 & 7.36 & 5.48 & 6.57 & 5.71 & 6.83 & 7.94 \\
\hline $\begin{array}{l}\text { Heat losses, kW } \\
\text { year / m2. }\end{array}$ & 77.98 & 63.05 & 52.88 & 45.55 & 55.6 & 46.46 & 58.71 & 49.18 & 42.28 \\
\hline $\begin{array}{l}\text { Expenses for } \\
\text { heating the air per } \\
\text { year, rubles }\end{array}$ & 116.97 & 94.58 & 79.32 & 68.33 & 83.4 & 69.69 & 88.07 & 73.77 & 63.42 \\
\hline $\begin{array}{l}\text { Savings per year, } \\
\text { rubles }\end{array}$ & 0 & 22.39 & 37.65 & 48.64 & 0 & 13.71 & 0 & 14.3 & 24.65 \\
\hline $\begin{array}{l}\text { Payback period, } \\
\text { years }\end{array}$ & 0 & 32.63 & 38.8 & 45.05 & 0 & 66.19 & 0 & 6.6 & 7.67 \\
\hline
\end{tabular}

The payback period of measures to improve the heat-shielding properties of walls is more than 30 years, which transfers them from the category of economic feasibility to the category of other tasks: "independent house", "maximum energy saving". An increase in wall insulation is not cost-effective for customers.

The payback period of measures to improve the heat-shielding properties of the foundation is 66 years, and the reduction in heat loss through $1 \mathrm{~m} 2$ is $16 \%$ less. Based on the obtained calculations, we can also note the inappropriateness of increasing the thermal insulation of the foundation.

According to the calculation of the payback of thermal insulation of the roof, a more effective solution is to increase the insulation to $350 \mathrm{~mm}$, which will lead to a decrease in heat loss by $28 \%$. This is one of the best ways to save energy.

One of the sources of heat loss is window units. In this building, "RehauBlitzNew 60" windows with a thermal resistance of $0.65(\mathrm{~m} 2 * \mathrm{~K}) / \mathrm{W}$ are designed, which fully complies with the standardized thermal performance.

Installation options for energy-saving windows should be considered taking into account the payback period (table 7). 
Table 7. Results of window blocks payback calculation

\begin{tabular}{|l|c|c|c|c|c|c|c|}
\hline \multicolumn{1}{|c|}{ Indicators } & \multicolumn{7}{|c|}{ Name } \\
\cline { 2 - 8 } tzNew 60 & $\begin{array}{c}\text { RehauBli } \\
\text { razio 70 }\end{array}$ & $\begin{array}{c}\text { RehauIn } \\
\text { telio 80 }\end{array}$ & $\begin{array}{c}\text { Deceuni } \\
\text { nck } \\
\text { Bauete }\end{array}$ & $\begin{array}{c}\text { Deceuninc } \\
\text { k Favorite }\end{array}$ & $\begin{array}{c}\text { Deceunin } \\
\text { ckEforte }\end{array}$ & $\begin{array}{c}\text { Schüco } \\
\text { Corona } \\
\text { SI 82 }\end{array}$ \\
\hline $\begin{array}{l}\text { Glazing cost, } \\
\text { rubles }\end{array}$ & 7279 & 8443 & 10172 & 9813 & 13925 & 19975 & 14843 \\
\hline $\begin{array}{l}\text { Overpayment } \\
\text { for installation, } \\
\text { rubles }\end{array}$ & 0 & 1164 & 2893 & 2534 & 6646 & 12696 & 7564 \\
\hline $\begin{array}{l}\text { Thermal } \\
\text { resistance } \\
\text { (m2 } * \text { K) / W }\end{array}$ & 0.65 & 0.77 & 0.98 & 0.69 & 0.74 & 0.9 & 1.1 \\
\hline $\begin{array}{l}\text { Heat losses, kW } \\
\text { * year. }\end{array}$ & 892.3 & 753.2 & 591.8 & 840.6 & 783.8 & 644.4 & 527.3 \\
\hline $\begin{array}{l}\text { Expenses for } \\
\text { heating the air } \\
\text { per year, rubles }\end{array}$ & 1338.45 & 1129.8 & 887.7 & 1260.9 & 1175.7 & 966.6 & 790.95 \\
\hline $\begin{array}{l}\text { Savings per } \\
\text { year, rubles }\end{array}$ & 0 & 208.65 & 450.75 & 77.55 & 162.75 & 371.85 & 547.5 \\
\hline $\begin{array}{l}\text { Payback period, } \\
\text { years }\end{array}$ & 0 & 5.6 & 6.4 & 32.7 & 40.8 & 34.1 & 13.8 \\
\hline
\end{tabular}

Based on the obtained calculations in table 7, the window blocks "RehauIntelio 80 " are optimal in the ratio of payback and thermal conductivity.

Thus, in order to save energy, following measures were proposed:

1. Installation of supply and exhaust ventilation with rotary recuperator "VU 500";

2. Increase in thermal insulation of the roof by $100 \mathrm{~mm}$;

3. Use of window blocks "RehauIntelio 80".

The results of calculating heat losses taking into account implementation of a range of energy saving measures are given in summary table 8 . 
Table 8. Heat losses through building envelopes after implementation of a set of recommended energy-saving solutions

\begin{tabular}{|l|l|c|c|c|c|c|c|}
\hline \multirow{2}{*}{ № } & \multirow{2}{*}{ Name of premises } & \multicolumn{5}{|c|}{ Heat loss, W } & Total \\
\cline { 3 - 8 } & & Floor & Walls & Windows & Roof & Ventilation & \\
\hline 1 & Entrance Tambour & 64 & 213 & - & - & - & 277 \\
\hline 2 & Hallway & 106 & - & - & - & 40.6 & 146.6 \\
\hline 3 & Living room & 482 & 427 & 859 & - & 184.4 & 1952.4 \\
\hline 4 & Corridor & 119 & 232 & 97 & - & 45.2 & 419.2 \\
\hline 5 & $\begin{array}{l}\text { Kitchen-dining } \\
\text { room }\end{array}$ & 249 & 318 & 889 & - & 227 & 1621 \\
\hline 6 & Bathroom & 36 & 57 & - & - & 39.8 & 94.8 \\
\hline 7 & Parlour & 126 & 153 & 173 & - & 48 & 451 \\
\hline 8 & Wardrobe & 46 & - & - & - & 16.6 & 62.6 \\
\hline 9 & Garage & 564 & 850 & 173 & 429 & 215.8 & 2142.8 \\
\hline 10 & Room for heat & 77 & 149 & 75 & 58 & 84 & 424 \\
\hline 11 & Penerator & 49 & 177 & 86 & 37 & 53.4 & 345.4 \\
\hline 12 & Hall & - & 232 & 97 & 100 & 50.4 & 345.4 \\
\hline 13 & Bedroom & - & 433 & 173 & 142 & 113.6 & 405.4 \\
\hline 14 & Bedroom & - & 382 & 512 & 253 & 227 & 794.6 \\
\hline 15 & Bedroom & - & 382 & 512 & 253 & 227 & 1251 \\
\hline 16 & Wardrobe & - & 109 & - & 55 & 79.4 & 1251 \\
\hline 17 & Bathroom & - & 288 & 157 & 97 & 153.8 & 208.8 \\
\hline Total: & 1918 & 4402 & 3803 & 1424 & 1806 & 12286 \\
\hline
\end{tabular}

The estimated heat loss of the building counts $12286 \mathrm{Wh}$, which is lower before the implementation of energy saving measures by $10815 \mathrm{Wh} * \mathrm{~h}$.

Figure 4 shows the heat loss of a residential building after the implementation of energy-saving measures.

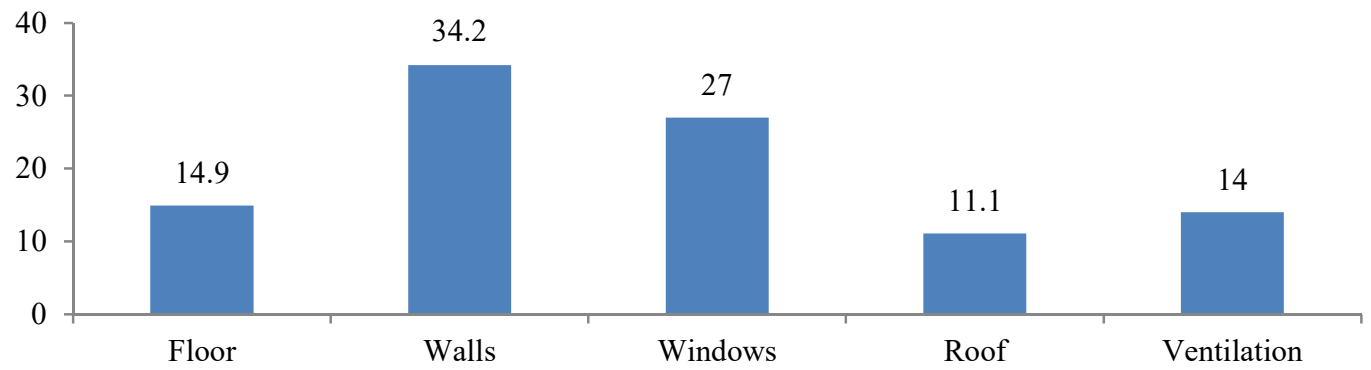

Fig. 4. Heat losses after the implementation of energy-saving measures, $\mathrm{kW} / \mathrm{m} 2$ * year

Heat loss calculations count $101.2 \mathrm{~kW} / \mathrm{m} 2$ * year, which corresponds to the "A" energy efficiency class of buildings. Heating costs according to the tariff for electricity, differentiated by three zones of the day, amounted to 109,455 rubles.

Effectiveness of these measures is indicated by the fact that heating costs decreased by 96,374 rubles.

Management of the entire heat supply system of the facility must be developed based on the simplicity of its operation, confirmed by practice. As controls, one can use widely available microprocessor temperature controllers with the possibility of programming in time. 
Table 9 shows the cost of microprocessor temperature controllers

Table 9. Cost of microprocessor temperature controllers

\begin{tabular}{|l|c|c|c|}
\hline \multicolumn{1}{|c|}{ Name } & $\begin{array}{c}\text { Price for 1 pc, } \\
\text { rubles }\end{array}$ & Amount needed, pcs & Total cost, rubles \\
\hline$\ll$ Valtec $»$ & 528 & 22 & 11616 \\
\hline$\ll$ RTC $»$ & 1266 & 8 & 10128 \\
\hline$\ll$ TC4S-24R $»$ & 3266 & 1 & 3266 \\
\hline
\end{tabular}

Total cost of all microprocessor temperature controllers was 25,010 rubles.

To assess the return on energy-saving measures, taking into account the growth of heat energy tariffs and discounting future cash receipts in accordance with the statement of work volumes, budget documentation was compiled on the basis of collections of federal unit rates (FER-2017 as amended by 1), 2017 edition. The appreciation index was adopted on the basis of the letter of the Ministry of Construction of Russian Federation dated 01.22.2019 No. 1408-LS / 09.

The estimated cost for implementation of existing energy-saving solutions is 646,292 thousand rubles. For implementation of new energy-saving solutions, the estimated cost of work is 903.378 thousand rubles. The difference in investment is 257,068 rubles.

Tariffs for heat and electricity in Russia are increasing every year. This leads to an increase in the cost of operating buildings. On average, the relative increase in tariffs for heat and electricity per year is $5 \%(\mathrm{r}=0.05)$.

It should also be borne in mind that future cash flows saved in subsequent years should be discounted. The discount rate for 2019 established by the Central Bank of Russian Federation is $7.5 \%(\mathrm{i}=0.075)$.

$$
T=\frac{\ln \left[1+\frac{\Delta K}{E} * \frac{(r-i)}{(1+i)}\right]}{\ln \left[\frac{1+r}{1+i}\right]}=\frac{\ln \left[1+\frac{257068}{96374} * \frac{(0,05-0,075)}{(1+0,075)}\right]}{\ln \left[\frac{1+0.05}{1+0.075}\right]}=2.7 \text { years }
$$

\section{Conclusions}

After the introduction of energy-saving solutions, selected residential project will fully comply with energy saving standards, both in terms of thermal insulation of building envelopes and in terms of specific heat consumption for heating during the heating season. However, energy-saving measures will become effective if the building's heat supply system is equipped with an automatic temperature control system in coolants.

According to the proposed calculation method, the payback period of investments in energy saving measures will be 2.7 years.

The above mentioned results can be used in the implementation of energy-saving measures during the construction of individual buildings in the Tyumen region and other regions of the relevant climatic conditions.

\section{References}

1. Yu. Matrosov, I. Butovsky, D. Goldstein. CENEF Bulletin, p. 15-20 (2014)

2. V. Bogoslovsky, V. Eminov. ABOK, 6, p.85 (2012)

3. Federal Law of the Russian Federation, № 261 (2009)

4. K. Gertis, Energy Saving, 3, p. 34-38 (2017)

5. L. Makhov, Energy Saving and Water Treatment, 1, p. 26-30 (2014) 
6. V. Rogatin, Methods for the rational design of single-family country houses (2014)

7. Yu. Tabunshchikov, M. Brodach, N. Shilkin, Energy Efficient Buildings (2017)

8. K. Fokin, ABOK, 8, p.83 (2016)

9. A. Minnullina, V. Vasiliev, Determining the Supply of Material Resources for HighRise Construction: Scenario Approach. E3S Web of Conferences 33, 03060 (2018), doi:10.1051/e3sconf/20183303060 